\title{
Lembar Kerja Peserta Didik Berbasis Kegiatan Transaksi Kewirausahaan Materi Sistem Persamaan Linier Dua Variabel
}

\author{
Novitasari Supardi ${ }^{*}$, Rosida RakhmAwati ${ }^{1}$, Achi Rinaldi ${ }^{1}$ \\ ${ }_{1}$ Universitas Islam Negeri Raden Intan Lampung, Jalan Endro Suratmin, Sukarame, Bandar \\ Lampung 35133, Indonesia \\ *Corresponding Author. E-mail: supardinovitasari@gmail.com Telp: +6285821784714
}

Received : 14-12-2017; Revised : 14-12-2017; Accepted : 29-01-2018

\begin{abstract}
Abstrak
Penelitian ini bertujuan Menghasilkan produk berupa LKPD pada materi sistem persamaan linier dua variabel (SPLDV), dan Mengetahui respon pendidik terhadap LKPD pada materi SPLDV. Metode penelitian ini adalah Research and Development (R\&D) berdasarkan model ADDIE dengan tahapan yang dilakukan yaitu dari analysis, design, development, implementation, evaluation. Hasil uji ahli materi pada aspek kualitas isi memperoleh rata-rata skor 3,67 dengan kriteria sangat baik, pada aspek ketepatan cakupan memperoleh rata-rata skor 3,167 dengan kriteria baik. Uji ahli media pada aspek ukuran LKPD memperoleh rata-rata skor 4 sangat menarik, aspek desain kulit LKPD memperoleh rata-rata skor 3,66 dengan kriteria baik, aspek desain isi LKPD memperoleh rata-rata skor 3,4167 dengan kriteria baik. Uji ahli bahasa memperoleh rata-rata skor 3,22 dengan kriteria baik. Pada uji coba kelompok kecil peserta didik pada uji kemenarikan memperoleh rata-rata skor sebesar 3,57 dengan kriteria menarik, uji coba kelompok besar peserta didik pada uji kemenarikan memperoleh rata-rata skor sebesar 3,56 dengan kriteria menarik. Dari beberapa data di atas, dapat disimpulkan bahwa LKPD yang dikembangkan masuk dalam kriteria baik dan mendapatkan respon yang baik bagi para peserta didik.
\end{abstract}

Kata Kunci : Lembar Kerja Peserta Didik, Sistem Persamaan Linier Dua Variabel

\begin{abstract}
This study aims to produce products in the form of LKPD SPLDV material, and Know the response of educators to LKPD on SPLDV material. The method of this research is Research and Development $(R \& D)$ based on ADDIE model Stages performed only from stage 1 to stage 5 that is from analysis, design, development, implementation, evaluation. The result of the material expert test on the content quality aspect obtained the average score of 3.67 with very good criteria, on the aspect of the accuracy of the scope obtained the average score of 3,167 with good criteria. Expert test media on LKPD size aspect got the average score 4 very interesting, skin design aspect LKPD got average score 3,66 with the good criterion, design aspect of LKPD got average score 3,4167 with good criterion. Expert tests obtained an average score of 3.22 with good criteria. In the small group trial of students in the attractiveness, test obtained an average score of 3.57 with interesting criteria, large group trials of students in the attractiveness test obtained an average score of 3.56 with interesting criteria. From some of the above data, it can be concluded that LKPD developed into good criteria and get a good response for the learners.
\end{abstract}

Keywords: Student Lecture Sheet, Two-Variable Linear Equation System 


\section{PENDAHULUAN}

Berkembang dan majunya zaman dapat dilihat dengan banyaknya muncul teknologi aplikasi-aplikasi komputer. Pada era kemajuan ilmu dan pendidikan saat ini, perlu adanya persiapan kita menyambut masa depan dengan berbenah diri serta memanfaatkan perkembangan ilmu dan teknologi yang telah tersedia (Sukring, 2016), karena pada umumnya masa depan kita adalah tujuan hidup yang ingin kita capai. Namun tak akan seutuhnya kita miliki masa depan yang baik tanpa melalui pendidikan. Melalui pendidikan, manusia dapat berkembang sesuai dengan apa yang diinginkan. Proses pendidikan tidaklah luput dari menuntut ilmu, karena hal ini merupakan salah satu cara mencapai derajat hidup yang berkualitas dan bermanfaat bagi masing-masing individu dan bagi orang lain (Gusnidar, Netriwati, \& Putra, 2018). Dalam proses menuntut ilmu, di dunia pendidikan diperlukan suasana belajar yang baik.

Mewujudkan suasana belajar dan proses belajar-mengajar yang interaktif merupakan tugas bagi pendidik yang berat, yang pada akhirnya agar potensi diri peserta didik dapat dikembangkan dengan baik agar memiliki kepribadian, kecerdasan, serta keterampilan yang diperlukan dirinya dan masyarakat (Yusnita, Masykur, \& Suherman, 2016). Bukunola dalam Widyawati menyatakan bahwa pendidikan merupakan cara dalam mengenalkan pada manusia untuk memiliki pengetahuan dan sikap yang lebih baik terlebih lagi belajar matematika yang didalam ada sifat tanggung jawab (Widyawati, 2016). Matematika merupakan pelajaran yang terstruktur, terorganisasi, dan berjenjang, artinya adanya kaitan antara beberapa materi yang ada di dalamnya. Matematika adalah salah satu pelajaran yang mampu mengembangkan kemampuan kreativitas dan menekankan pada pemecahan masalah (Susandi \& Widyawati, 2017). Memecahkan masalah Dalam pembelajaran matematika adalah hal yang penting, bahkan dapat dikatakan jantungnya matematika (Yuliyanto \& Jailani, 2014). Akan tetapi sudah terlalu umum pada saat ini pembelajaran matematika tepusat pada guru sehingga pembelajaran lebih cenderung pasif. Siswa hanya menikmati kejenuhannya dalam pembelajaran matematika yang selalu berkutat dengan pembelajaran seperti itu.

Melihat problem tersebut, sudah sepatutnya pendidik harus membuat inovasi-inovasi terbaru dalam pembelajarannya sehingga peserta didik tidak merasa jenuh, bosan dan selalu termotivasi dalam pembelajaran matematika. Inovasi-inovasi tersebut bisa saja dalam pengguanaan model pembelajaran ataupun media pembelajaran. Inovasi dalam pembelajaran ini tentunya tidak terlepas dari kreatifitas dan keinginan para guru itu sendiri dalam perhatiannya kepada siswa. Media pembelajaran seharusnya sudah bisa dimanfaatkan oleh para pendidik dalam pembelajaran matematika. Media Pembelajaran dengan Lembar Kerja Peserta Didik merupakan salah satu alternatif pembelajaran yang tepat bagi peserta didik karena LKPD membantu peserta didik untuk menambah informasi tentang konsep yang dipelajari melalui kegiatan belajar secara sistematis (Sudrajat \& Muslim, 2012).

Lembar Kerja Peserta Didik (LKPD) merupakan sarana pembelajaran yang dapat digunakan peserta didik dalam meningkatkan keterlibatan atau aktivitas peserta didik dalam proses belajar mengajar. Pada umumnya, LKPD berisi petunjuk praktikum, percobaan yang bisa dilakukan dirumah, materi untuk 
Desimal, 1 (1), 2017 - 51

Novitasari S, Rosida Rakhmawati M, Achi Rinaldi

diskusi, dan soal-soal latihan maupun segala bentuk petunjuk yang mampu mengajak peserta didik beraktivitas dalam proses pembelajaran (Damayanti, Ngazizah, \& Setyadi K, 2013). LKPD sangat baik dipakai untuk meningkatkan keterlibatan peserta didik dalam proses pembelajaran.

Sehingga peneliti tertarik untuk mengembangkan Lembar Kerja Peserta Didik dalam pembelajaran Matematika. Beberapa penelitian dengan mengembangkan LKPD ini pernah dilakukan sebelumnya Herman, perbedaan dalam penelitian ini adalah penelitian ini dilakukan pada mata pelajaran fisika berbasis ketrampilan sedangkan dalam penelitian ini dilakukan dalam pembelajaran matematika berbasis kewirausaan (Herman \& Aslim, 2015).

\section{METODE}

Penelitian ini menggunakan metode penelitian dan pengembangan (Research and Development). Metode penelitian merupakan cara yang digunakan oleh peneliti dalam mengumpulkan data penelitian. Penelitian ini mengacu pada model yang dikembangkan oleh Dick and Carry yaitu, ADDIE model ini meliputi: 1) Analysis, 2) Design, 3) Development, 4) Implementasi, dan 5) Evaluasi. Berdasarkan pendapat di atas dapat dikatakan bahwa penelitian dan pengembangan dibidang pendidikan merupakan jenis penelitian yang bertujuan untuk mengembangkan sekaligus memvalidasi produk pendidikan dan pembelajaran. Produk dari jenis penelitian ini diharapkan dapat digunakan untuk meningkatkan dan mengembangkan mutu pendidikan dan pembelajaran.

Tabel 1 Skor Validasi Ahli (dimodifikasi)

\begin{tabular}{cc}
\hline Skor & Pilihan Jawaban Kelayakan \\
4 & Sangat Baik \\
3 & Baik \\
2 & Kurang Baik \\
1 & Sangat Kurang Baik \\
\hline
\end{tabular}

Selanjutnya data hasil perolehan skor dicari rata-ratanya dengan menggunakan rumus berikut:

$$
\bar{x}=\frac{\sum_{i=1}^{n} x_{i}}{n}
$$

Dengan:

$$
\mathrm{X}_{\mathrm{i}}=\frac{\text { jumlah } \text { skor }}{\text { skor maks }} \times 4
$$

Keterangan : $\bar{x}=$ rata - rata akhir $x_{i}=$ nilai uji operasional angket tiap peserta didik $n$ = banyaknya aspek butir

soal

Kemudian hasil angket yang diperoleh dari validasi ahli dikategorikan sesuai dengan interpretasi pada tabel berikut ini:

Tabel 2 Kriteria Validasi (dimodifikasi)

\begin{tabular}{ccc}
\hline Skor Kualitas & Kriteria Kelayakan & Keterangan \\
$3,26<\overline{\mathrm{x}} \leq 4,00$ & Valid & Tidak Revisi Revisi sebagian \\
$2,51<\overline{\mathrm{x}} \leq 3,26$ & Cukup Valid & Revisi sebagian \\
$1,76<\overline{\mathrm{x}} \leq 2,51$ & Kurang Valid & Revisi sebagian \& pengkajian ulang materi \\
$1,00<\overline{\mathrm{x}} \leq 1,76$ & Tidak Valid & Revisi Total \\
\hline
\end{tabular}


Desimal, 1 (1), 2018 - 52

Novitasari S, Rosida Rakhmawati M, Achi Rinaldi

Sedangkan hasil angket yang diperoleh dari peserta didik dan

pendidik disesuaikan dengan tebel interpretasi berikut ini:

Tabel 3 Kriteria Validasi (dimodifikasi)

Skor Kualitas
$3,26<\overline{\mathrm{x}} \leq 4,00$
$2,51<\overline{\mathrm{x}} \leq 3,26$
$1,76<\overline{\mathrm{x}} \leq 2,51$
$1,00<\overline{\mathrm{x}} \leq 1,76$

Pertanyaan Kualitas Aspek Kemenarikan

00

26

, 76

Sangat Menarik Revisi sebagian Menarik

Kurang Menarik

Sangat kurang Menarik

Produk pengembangan akan berakhir saat skor penilaian terhadap modul ini telah memenuhi syarat kelayakan dengan tingkat kesesuaian materi dan desain, dikategorikan sangat menarik atau manarik.

\section{HASIL DAN PEMBAHASAN}

Hasil pengembangan yang dilakukan oleh peneliti ini adalah menghasilkan Modul Desain Didaktis. Penelitian dan pengembangan ini dilakukan dengan menggunakan prosedur dan pengembangan 4D yang dilakukan dari tahap pendefinisian (Define), tahap perancang an (Design), tahap pengembangan (Devel op), tahap penyebaran (Dessiminate). Data hasil setiap tahapan prosedur penelitian dan pengembangan yang dilakukan adalah sebagai berikut:

\section{Analysis (Analisis)}

Berdasarkan tahap analisis yang telah dijelaskan pada hasil penelitian diketahui bahwa pada proses pembelajaran terlihat masih banyak peserta didik yang pasif maka sangat perlu melakukan persiapan rancangan bahan ajar yang memperhatikan respon peserta didik, maka peneliti mengembangkan bahan ajar berbasis kewirausahaan pada materi SPLDV.

Pemilihan berbasis kewirausahaan pada pembuatan bahan ajar LKPD yang dikembangkan karena dalam kehidupan sehari-hari peserta didik selalu melakukan kegiatan transaksi

$\begin{array}{lcrr}\text { kewirausahaan } & \text { dimana } & \text { sangat } \\ \text { diperlukan ilmu } & \text { pengetahuan } & \text { terkait } \\ \text { perhitungannya, } & \text { hal ini } & \text { juga } \\ \text { dikarenakan } & \text { LKPD } & \text { berbasis }\end{array}$
kewirausahaan mampu dikembangkan sehingga sal-soal berbentuk cerita terkait kegiatan transaksi kewirausahaan yang bermanfaat bagi kehidupan sehari-hari. Sehingga lebih membantu pendidik dalam menyampaikan materi serta pemberian soal-soal agar lebih menarik.

\section{Design (Perancangan)}

Setelah melakukan analisis kebutuhan maka tahap selanjutnya adalah tahap design. Adapun tahap perancangan (design) yang pertama adalah pemilihan bahan ajar, pemilihan format serta rancangan awal bahan ajar.

\section{Develop (Pengembangan)}

Tahap selanjutnya setelah tahap perancangan bahan ajar, kemudian peneliti melakukan tahap pengembangan (development) yang merupakan tahap utama dalam membuat atau mengembangkan LKPD menjadi satu kesatuAn yang utuh serta melakukan validasi oleh ahli, tujuan dilakukan validasi adalah untuk memperoleh masukan, kritik serta guna perbaikan untuk kesempurnaan LKPD yang dikembangkan sehingga prodak telah layak diimplementasikan kepada subyek penelitian. 
Desimal, 1 (1), 2017 - 53

Novitasari S, Rosida Rakhmawati M, Achi Rinaldi

a. Validasi

1. Hasil Validasi Ahli Materi

Hasil validasi ahli materi pada produk disajikan dalam bentuk grafik berikut:

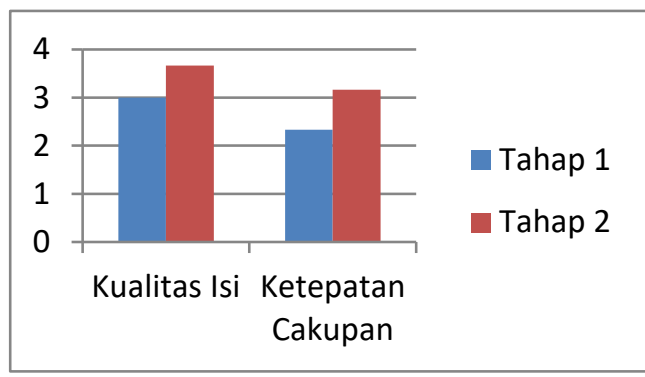

Gambar 1. Hasil validasi ahli materi

Berdasarkan hasil validasi oleh ahli materi pada produk awal diperoleh skor persentase rata-rata Adapun nilai untuk aspek kualitas isi pada tahap 1 diperoleh rata-rata skor sebesar 3 dengan kriteria "cukup valid" dan pada tahap 2 rata-rata skor kualitas isi sebesar 3,67 dengan kriteria "valid". Aspek ketepatan cakupan pada tahap 1 diperoleh ratarata skor sebesar 2,33 dengan kriteria "kurang valid" dan pada tahap 2 diperoleh rata-rata sebesar 3,167 dengan kriteria "cukupn valid".

\section{Hasil Validasi Ahli Media}

Hasil validasi oleh ahli media pada produk disajikan dalam bentuk grafik berikut:

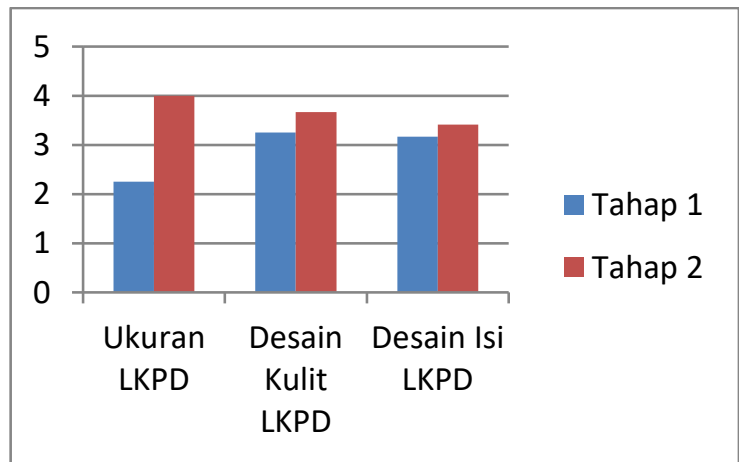

Gambar 2. Hasil validasi ahli media
Adapaun nilai untuk aspek ukuran LKPD pada tahap 1 diperoleh rata-rata skor 2,25 dengan kriteria "kurang valid" dan pada tahap 2 rata-rata skor aspek ukuran LKPD sebesar 4 dengan kriteria "valid".

Rata-rata skor untuk aspek desain kulit LKPD pada tahap 1 adalah 3,25 dengan kriteria "cukup valid" dan pada tahap 2 rata-rata skor aspek desain kulit LKPD sebesar 3,67 dengan kriteria "valid". Sedangkan rata-rata skor aspek desain isi LKPD pada tahap 1 sebesar 3,167 dengan kriteria "cukup valid" dan pada tahap 2 rata-rata skor aspek desain isi LKPD sebesar 3,4167 dengan kriteria "valid".

\section{Hasil Validasi Ahli Bahasa}

Hasil validasi oleh ahli media pada produk disajikan dalam bentuk grafik berikut:

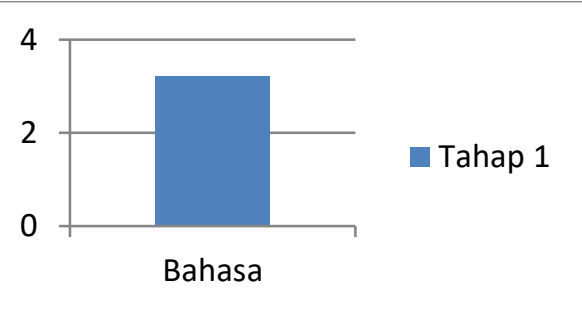

\section{Gambar 3. Hasil validasi ahli bahasa}

Adapun nilai untuk Aspek kebahasaan pada tahap 1 memperoleh nilai rata-rata 3,22 dengan kriteria "cukup valid", karena pada tahap 1 ahli bahasa memberikan saran serta perbaikan yang tidak begitu besar dan mendasar, maka tidak perlu dilakukan validasi ahli bahasa tahap 2 .

4. Hasil uji coba Produk

Uji coba terkait uji coba kemenarikan dilakukan pada uji coba skala kecil dan uji coba lapangan. Uji coba kelompok kecil diperoleh nilai rata-rata 3,54 , pada uji coba lapangan diperoleh nilai rata-rata 3,56 yang termasuk dalam kategori sangat layak. Hal tersebut menunjukkan bahwa LKPD berbasis kewirausahaan pada materi 
SPLDV yang dikembangkan memiliki kemenarikan sebagai alat bantu belajar, dalam hal kualitas isi serta tampilan LKPD. Hasil uji coba disajikan dalam bentuk grafik berikut:

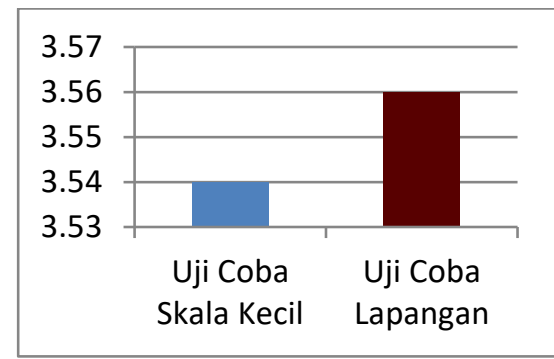

Gambar 4. Hasil Uji Coba

Berdasarkan gambar 2. Dapat dilihat hasil uji coba 2 kali dilakukan pada skala kecil memperoleh skor 3,54 hasil ini berada pada kriteria LKPD sangat menarik digunakan dalam pemebelajaran matematika. Berdasarkan hasil uji coba hasil lapangan (skala besar) hasil diluar dugaan yaitu hasil angket mencapai skor rata-rata 3,56 yang berarti pada kriteria sangat menarik. Dengan hasil 2 kali uji coba penelitian bahwa LKPD yang telah dikembangkan hasil penelitian ada pada kriteria sangat menarik untuk digunakan dalam pembelajaran matematika. Berdasarkan hasil penelitian ini peneliti menyimpulkan bahwa peserta didik lebih menyukai pembelajaran yang real nyata seperti penggunaan media pembelajaran. Hasil penelitian ini sama dengan hasil penelitian oleh Hasil dengan hasil pengembangan LKPD yang dikembangkan mendapatkan respon yag baik pada peserta didik (Herman \& Aslim, 2015).

\section{SIMPULAN DAN SARAN}

Kesimpulan dari penelitian dan pengembangan ini antara lain Lembar Kerja Peserta Didik (LKPD) Berbasis Kewirausahaan pada Materi SPLDV yang dihasilkan telah dikembangkan dengan prosedur penelitian dan pengembangan
Dick and Carrey yaitu ADDIE yang meliputi tahapan analisys, design, development, implementasion, dan evaluation serta Respon peserta didik terhadap Lembar Kerja Peserta Didik (LKPD) pada Materi SPLDV memperoleh nilai rata-rata 3,56; dan respon pendidik terhadap Lembar Kerja Peserta Didik (LKPD) Berbasis Kewirausahaan pada Materi SPLDV memperoleh nilai ratarata 3,5 .

Berdasarkan beberapa hal yang telah disampaikan sebelumnya. Penulis dapat memberikan saran untuk para pendidik agar menggunakan LKPD dalam proses pembelajarannya, dan dapat mengembangkan media-media pembelajaran yang lainnya agar kemampuan matematika peserta didik dapat lebih baik lagi.

\section{DAFTAR PUSTAKA}

Damayanti, D. S., Ngazizah, N., \& Setyadi K, E. (2013). Pengembangan Lembar Kerja Siswa ( LKS ) Dengan Pendekatan Inkuiri Terbimbing Untuk Mengoptimalkan Kemampuan Berpikir Kritis Peserta Didik Pada Materi Listrik Dinamis SMA Negeri 3 Purworejo Kelas X Tahun Pelajaran 2012 / 2013. Radiasi, 3(1), 58-62.

Gusnidar, G., Netriwati, N., \& Putra, F. G. (2018). Implementasi Strategi Pembelajaran Konflik Kognitif Berbantuan Software Wingeom Dalam Meningkatkan Kemampuan Pemecahan Masalah Matematis. Jurnal Edukasi Matematika Dan Sains, 5(2), 62-69.

Herman, H., \& Aslim, A. (2015). Pengembangan LKPD Fisika Tingkat SMA Berbasis Keterampilan Proses Sains. In Prosiding Seminar Nasional Fisika (Vol. IV, pp. 113118).

Sudrajat, D., \& Muslim, T. (2012). Perancangan Aplikasi Game Aritmatika pada Handphone untuk 
Desimal, 1 (1), 2017 - 55

Novitasari S, Rosida Rakhmawati M, Achi Rinaldi

Melatih Kemampuan Berhitung

Kelas 1 dan 2 Sekolah Dasar Negeri II Ciperna Kabupaten. Jurnal ICT, 7(1), 112-120.

Sukring, S. (2016). Pendidik dalam Pengembangan Kecerdasan Peserta Didik (Analisis Perspektif Pendidikan Islam ). Tadris: Jurnal Keguruan Dan Ilmu Tarbiyah, 1(1), 69-80.

Susandi, A. D., \& Widyawati, S. (2017). Proses Berpikir dalam Memecahkan Masalah Logika Matematika Ditinjau dari Gaya Kognitif Field Independent dan Field Dependent. NUMERICAL: Jurnal Matematika Dan Pendidikan Matematika, 93112.

Widyawati, S. (2016). Pengaruh Kemampuan Koneksi Matematis Siswa terhadap Prestasi Belajar Matematika Ditinjau dari Gaya Belajar pada Materi Bangun Ruang Sisi Datar Siswa Kelas IX SMP di Kota Metro. Iqra': Jurnal Kajian Ilmu Pendidikan, 1(1), 47-68.

Yuliyanto, Y., \& Jailani, J. (2014). Pengembangan Perangkat Pembelajaran Geometri SMP Menggunakan Metode Penemuan Terbimbing pada Kelas VIII Semester II. Jurnal Riset Pendidikan Matematika, 1(1), 127-138.

Yusnita, I., Masykur, R., \& Suherman, S. (2016). Modifikasi Model Pembelajaran Gerlach dan Ely Melalui Integrasi Nilai-Nilai Keislaman Sebagai Upaya Meningkatkan Kemampuan Representasi Matematis. Al-Jabar: Jurnal Pendidikan Matematika, 7(1), 29-38. 